\title{
Constraints and Suggestions as Expressed by Redgram Growers in North-Eastern Karnataka, India
}

\author{
Ashokkumar Bansilal ${ }^{1 *}$, K. Venkataranga Naika ${ }^{1}$, N. S. Shivalinge Gowda ${ }^{1}$, \\ V. Manjunath ${ }^{2}$ and H. M. Jayadeva ${ }^{3}$
}

${ }^{1}$ Department of Agricultural Extension, University of Agricultural Sciences, GKVK, Bengaluru- 560065

${ }^{2}$ Department of Agricultural Statistics, Computer Sciences and Applied Mathematics, University of Agricultural Sciences, GKVK, Bengaluru- 560065

${ }^{3}$ Dept. of Agronomy, University of Agricultural Sciences, GKVK, Bengaluru- 560065, India

*Corresponding author

\begin{tabular}{|l|}
\hline K e y w o r d s \\
Constraints, \\
Suggestions, \\
Redgram,Cost of \\
production, \\
Minimum Support \\
Price, Supervision \\
and Guidance \\
\hline Article Info \\
\hline $\begin{array}{l}\text { Accepted: } \\
\text { 20 December } 2019 \\
\text { Available Online: } \\
\text { 10 January } 2020\end{array}$ \\
\hline
\end{tabular}

\section{A B S T R A C T}

In India, redgram mainly grown in many states like Maharashtra, Madhya Pradesh, Karnataka, Andra Pradesh, Rajasthan and Uttar Pradesh and it occupies 3.89 million hectares of area with the about 3.30 million tonnes of production, having yield of $849 \mathrm{~kg}$ per hectare on an average. In Karnataka, redgram accounts an area of 0.82 million hectares with the 0.61 million tonnes of production, having an average productivity of $733 \mathrm{~kg}$ per ha. Present study was conducted in NorthEastern region of Karnataka state during the year 2016-18,to identify the constraints and suggestions as expressed by redgram growers. The data were collected from the randomly selected 180 redgram growers through personal interview method using structured pre-tested interview schedule. Results indicated that, constraints faced by farmers in managing redgram crop, among the production constraints scarcity of labour $(90.00 \%)$ was the main constraint expressed by the respondents. The constraints related to crop marketing concerned, it was clearly observed that fluctuation in prices $(88.89 \%)$, with respect to technical constraints, lack of timely and adequate supply of input stood first rank $(81.11 \%)$. The major economic constraints expressed were high cost of production $(92.22 \%)$ and with respect to extension constraints, lack of frequent technical supervision and guidance $(72.78 \%$ ) were the major constraint expressed by redgram growers. The suggestion expressed by redgram growers for improving redgram cultivation, the results revealed that more than 80 per cent of redgram growers suggested High MSP (Minimum Support Price) for redgram (89.44 \%) followed by reduction in the cost of inputs $(88.89 \%)$ and more of government subsidies $(86.67 \%)$. 


\section{Introduction}

Pulses play a crucial role in Indian farming. Pulses have abundant amount of protein and they contain important amino acids and therefore are the part of predominantly vegetarian population of India. It contains 2224 per cent of protein, which is almost twice the protein in wheat and thrice as that of rice. India stands first in area and production under pulses. It contributes 25 and 27 percent to the worlds' pulse production and consumption, respectively. Since from the last thirty years the trend has shown that there is a reduction in contribution of pulses to the total food grain production. The current status of pulse production in terms of area is 23.47 million hectare with the production of 18.34 million tonnes and productivity being $781 \mathrm{~kg} / \mathrm{ha}$. The present demand for pulses in the country is 17 million tonnes whereas the production is less than the requirement i.e., 15.19 million tonnes. In India the states like, Madhya Pradesh followed Maharashtra, Uttar Pradesh, Andhra Pradesh, Karnataka and Rajasthan are the major pulse growing states. The contribution of above mentioned states to the total pulse production of the country is 80 per cent (Anon., 2016).

Pigeonpea or Redgram stands in the list of the major pulse crops of the tropics and subtropics, this has grown in approximately 50 countries in Asia, Africa and Americas, mostly as an intercrop with cereals. It is commonly known as pigeonpea, redgram, tur, arhar, tuvarica, congobean, thogari or gandul in India. Redgram stood 6th (sixth) rank in area and production in comparison to other pulses such as beans, peas, and chickpeas. In India, Pigeonpea or redgram mainly grown in many states like Maharashtra, Madhya Pradesh, Karnataka, Andra Pradesh, Rajasthan and Uttar Pradesh and it occupies 3.89 million hectares of area with the about 3.30 million tonnes of production, having yield of $849 \mathrm{~kg}$ per hectare on an average, Anon (2016). In Karnataka, redgram accounts an area of 0.82 million hectares with the 0.61 million tonnes of production, having an average productivity of $733 \mathrm{~kg}$ per ha. It is largely cultivated in northern parts of Karnataka like, Kalaburgi (Gulbarga), Vijayapura (Bijapur), Bidar and Yadgir districts. Thus, North-East Karnataka region is called as "Pulsebowl of Karnataka". Adoption of recommended technologies and proper management techniques helps in enhancing the productivity of redgram. Majority of the farmers in the area has undertaken the cultivation of redgram since a very long time. However, it is observed that recommended redgram production technology is not adopted by the farmers upto the extent for higher production due to some production, marketing, technical, economical and extension constraints. Therefore, study was conducted to identify the constraints faced by farmers in managing redgram crop and to seek their suggestions to over-come these constraints.

\section{Materials and Methods}

The study conducted to identify the constraints and suggestions expressed by redgram growers. The research study conducted in North Eastern region of Karnataka state mainly in 3 districts viz, Bidar, Kalaburgi and Yadgir during the year 2016-18. These districts were purposively selected as these ranks first, second and third in area and production of redgram. In each district two taluks were selected and from each taluk two village were selected for the study. Thus, 30 respondents were selected from one taluka. In each village, 15 redgram growers were randomly selected. Thus, constituting total sample size is 180. Ex-post fact research design suitable for the study and employed. Personal interview technique was used for data collection. Thereafter data were 
tabulated, analysed and interpreted in the light of objectives of the study.

\section{Results and Discussion}

\section{Constraints expressed by redgram growers}

In recent days farmers are facing lot of problems in agriculture, same thing in redgram cultivation too the farmers had experienced many constraints. From the Table 1 it could be observed that, the constraints of five fold viz., related to production, marketing, technical, economic and extension were presented in Table 1. Among the production constraints viz., Scarcity of labour $(90.00 \%)$ was the main constraint expressed by the respondents.

Non-availability of planting material (83.88 $\%)$, Problem of water scarcity $(73.33 \%)$ and Uncertainty of rainfall $(56.67 \%)$ were also the important constraints expressed by their spondents.

So far as the constraints related to crop marketing concerned, it was clearly observed that Fluctuation in prices $(88.89 \%)$, Lack of market information $(82.77 \%)$ and Poor transportation facility $(76.11 \%)$ were the major constraints expressed by respondents. Delay in payment (56.67 \%), Exploitation by middlemen (52.78\%), improper weighment (49.44\%) and Limited access to regulated market (43.33 \%) were also important constraints reported by farmers.

With respect to technical constraints, lack of timely and adequate supply of input stood first rank $(81.11 \%)$ followed by Nonavailability of quality inputs (Seeds, FYM, fertilizers). Other technical constraints expressed by farmers were Lack of skill on chemical spray (60.00\%), Infection of pest and diseases $(54.44 \%)$ followed by Lack of knowledge on production of redgram.
The major economic constraints expressed were high cost of production (92.22\%), High wages of labour $(83.88 \%)$ and Insufficient credit $(60.56 \%)$. With respect to extension constraints, lack of frequent technical supervision and guidance $(72.78 \%)$ was the major extension constraint faced by farmers followed by Lack of demonstration and trainings on recommended practices (66.67 $\%)$.

Now-a-days the labour cost had increased and availability of labour became difficultly for the cultivation activities. Even the farmers were producing the crops in many consequences but they could not get remunerative prices in the market for their produce and the price fluctuation in day by day is increasing, the farmers might had brought loan and they were not in position to store their produce for selling in future, so in a low price also they sale their produce without getting remunerative price for their produce so, it directly leads to distress sale.

\section{Suggestion expressed by redgram growers for improving redgram cultivation}

An attempt was made to know the suggestions of the farmers to overcome the various problems faced by them. The responses of farmers in this regard were presented in Table 2. The results revealed that more than 80 per cent of redgram growers suggested High MSP (Minimum Support Price) for redgram (89.44 $\%$ ) followed by reduction in the cost of inputs $(88.89 \%)$ and more of government subsidies $(86.67 \%)$.

Nearly three-fourths of the farmers stated that there is need of assured market for redgram $(77.78 \%)$ followed by provision of timely and adequate payment for the produce $(75.00$ $\%$ ) and Provision of timely and adequate credit for the produce $(73.33 \%)$. 
Table.1 Constraints experienced by redgram growers $\quad(n=180)$

\begin{tabular}{|c|c|c|c|c|}
\hline Sl. No. & Constraints faced by farmers in managing redgram crop & $\mathbf{F}$ & $\%$ & Rank \\
\hline $\mathbf{I}$ & Production constraints & & & \\
\hline 1 & Scarcity of labour & 162 & 90.00 & 1 \\
\hline 2 & Non-availability of planting material & 151 & 83.88 & 2 \\
\hline 3 & Problem of water scarcity & 132 & 73.33 & 3 \\
\hline 4 & Uncertainty of rainfall & 102 & 56.67 & 4 \\
\hline II & Marketing constraints & & & \\
\hline 1 & Fluctuation in prices & 160 & 88.89 & 1 \\
\hline 2 & Lack of market information & 149 & 82.77 & 2 \\
\hline 3 & Poor transportation facility & 137 & 76.11 & 3 \\
\hline 4 & Delay in payment & 102 & 56.67 & 4 \\
\hline 5 & Exploitation by middlemen & 95 & 52.78 & 5 \\
\hline 6 & Improper weighment & 89 & 49.44 & 6 \\
\hline 7 & Limited access to regulated market & 78 & 43.33 & 7 \\
\hline III & Technical constraints & & & \\
\hline 1 & Lack of timely and adequate supply of input & 146 & 81.11 & 1 \\
\hline 2 & Non-availability of quality inputs (Seeds, FYM, fertilizers) & 128 & 71.11 & 2 \\
\hline 3 & Lack of skill on chemical spray & 108 & 60.00 & 3 \\
\hline 4 & Infection of pest and diseases & 98 & 54.44 & 4 \\
\hline 5 & Lack of knowledge on production of redgram & 71 & 39.44 & 5 \\
\hline IV & Economic constraints & & & \\
\hline 1 & High cost of production & 166 & 92.22 & 1 \\
\hline 2 & High wages of labour & 151 & 83.88 & 2 \\
\hline 3 & Insufficient credit & 109 & 60.56 & 3 \\
\hline $\mathbf{V}$ & Extension constraints & & & \\
\hline 1 & Lack of frequent technical supervision and guidance & 131 & 72.78 & 1 \\
\hline 2 & Lack of demonstration and trainings on recommended practices & 120 & 66.67 & 2 \\
\hline 3 & Lack of trained officials & 107 & 59.44 & 3 \\
\hline 4 & Lack of storage facilities & 85 & 47.22 & 4 \\
\hline 5 & Lack of practical oriented training & 55 & 30.56 & 5 \\
\hline
\end{tabular}

$\mathrm{F}=$ Frequency 
Table.2 Suggestions expressed by redgram growers in improving redgram cultivation

\begin{tabular}{|r|l|c|c|c|}
\hline $\begin{array}{c}\text { SI. } \\
\text { No. }\end{array}$ & \multicolumn{1}{|c}{ Suggestions } & F & \% & Rank \\
\hline $\mathbf{1}$ & High MSP for redgram & 161 & 89.44 & 1 \\
\hline $\mathbf{2}$ & Reduction in the cost of inputs & 160 & 88.89 & 2 \\
\hline $\mathbf{3}$ & More of government subsidies & 156 & 86.67 & 3 \\
\hline $\mathbf{4}$ & Assured market for redgram & 140 & 77.78 & 4 \\
\hline $\mathbf{5}$ & Provision of timely and adequate payment for the produce & 135 & 75.00 & 5 \\
\hline $\mathbf{6}$ & Provision of timely and adequate credit for the produce & 132 & 73.33 & 6 \\
\hline $\mathbf{7}$ & Protection from middlemen exploitation & 107 & 59.44 & 7 \\
\hline $\mathbf{8}$ & $\begin{array}{l}\text { Provision for suitable market infrastructure (transportation, storage, } \\
\text { weighment facilities) }\end{array}$ & 101 & 56.11 & 8 \\
\hline $\mathbf{9}$ & $\begin{array}{l}\text { Timely and adequate information regarding availability of inputs, } \\
\text { prices, arrivals etc }\end{array}$ & 95 & 52.78 & 9 \\
\hline $\mathbf{1 0}$ & Providing interest free credit & 90 & 50.00 & 10 \\
\hline $\mathbf{1 1}$ & More professional guidance & 89 & 49.44 & 11 \\
\hline $\mathbf{1 2}$ & Development of pest and disease tolerant varieties & 71 & 39.44 & 12 \\
\hline $\mathbf{1 3}$ & Use of recommended practice properly & 45 & 25.00 & 13 \\
\hline & & & \\
\hline
\end{tabular}

$\mathrm{F}=$ Frequency

Majority of the respondents had suggested that the less cost of inputs as the inputs rate had become more and in redgram the farmers could not get remunerative prices for their produce, sometimes what they had invested for cultivation they could not get that back. Even farmers were producing enough produce but they could not getting remunerative prices for their produce because there is less MSP for their produce. As Kalaburagi (Gulbarga) was the drought area the farmers want the drought, pest and disease resistant varieties to overcome the crop failure and to increase the farmers' income. The farmers were not aware of the newly launched government schemes and other benefits regarding agriculture and process, they want the updated information to improve their livelihood. The availability of inputs were not in appropriate time that leads to inefficient growth and yield of the crops. For each and every activity one could need the guidance for growing the crops and have 
to inform the newly developed innovations so that farmers may practice and get good income in farming activity. The farmers had suggested that they wanted need based training, regarding their crop the new innovation or practices trainings may help them to make the farming easy and more income oriented one. Most of the villages do not have storage facilities for the farmers produce so the farmers might sell their produce in the local market with low prices, even sometimes they sell to the middlemen.

\section{References}

Adekunle, O. O., 2013, Analysis of effectiveness of agricultural extension service in among rural women: Case study of Odeda local government, Ogun state, Nigeria. J. Agril. Sci., 5(12): 6571.

Anonymous, 2016, Status paper on pulses, GOI, Directorate of Pulses Development in Bhopal, pp: 3-28.

Bandgar, S. G., Kude, N. R., and Bhople, R. S., 2004, Adoption of University recommended cotton technologies and the constraints faced by the farmers.
PKV. Res. J. 28(1): 91-95.

Basavaraj, J. Gundappagol, 2014, Management efficiency of vegetable growers of Belgaum district. M.Sc. (Agri.) Thesis (Unpub.), Univ. Agric. Sci., Dharwad.

Kharatmol, 2006, Impact of trainings conducted on vermicompost by Krishi Vigyan Kendra, Bijapur. M. Sc. (Agri.) Thesis, Uni. Agric. Sci., Dharwad.

Kumar Praveen, Rajinder Peshin, Nain, M. S. and Manhas, J. S. 2010, Constraints in pulses cultivation as perceived by the farmers. Rajasthan. J. Extn. Edu., 17 \& 18: 33-36.

Shashikant, V. G. ItigiPrabhakar, B. Manjunatha, L. and Sharma, J. P., 2011, Constraints in production and marketing of redgram in Gulbarga district of Karnataka. J. Com. Mob. \& Sus. Dev.,6 (2): 202-204.

Singh, D. K., Gautam, U. S. and Singh, R. K., 2007, A study on yield gap and level of demonstrated crop production technology in Sagar district. Indian Res. J. Ext. Edu., 7(2\&3): 94-95.

www.indiastat.com

\section{How to cite this article:}

Ashokkumar Bansilal, K. Venkataranga Naika, N. S. Shivalinge Gowda, V. Manjunath and Jayadeva, H. M. 2020. Constraints and Suggestions as Expressed by Redgram Growers in North-Eastern Karnataka, India. Int.J.Curr.Microbiol.App.Sci. 9(01): 1-6.

doi: https://doi.org/10.20546/ijcmas.2020.901.001 